\begin{tabular}{|l|l||r|}
\hline & Al Fitrah & \\
Journal Of Early Childhood Islamic Education & Pendidikan Resolusi Konflik Bagi Anak \\
Usia Dini \\
ISSN : 2599-2287 E-ISSN : 2622-335X \\
Vol.2 No.1 Juli 2018
\end{tabular}

\title{
PENDIDIKAN RESOLUSI KONFLIK BAGI ANAK USIA DINI
}

\begin{tabular}{l|l} 
Abstrak & Wira Hadi Kusuma \\
Kajian ini menjelaskan tentang Pendidikan & wirahadikusuma@iainbengkulu.ac.id \\
resolusi konflik bagi anak usia dini. Pendidikan & IAIN Bengkulu \\
resolusi konflik pada anak usia dini merupakan & \\
hal yang sangat urgen. Hal ini disebabkan anak & \\
usia dini adalah pondasi awal dalam penanaman & \\
dan penengenalan serta pembiasaan karakter & \\
damai dalam menyelesaikan konflik. Dalam & \\
mengembangkan pendidikan resolusi konflik bagi & \\
anak usia dini, perlu memperhatikan tentang & \\
pendidikan menguraikan masalah, pemecahan & \\
masalah dan menghilangkan permasalahan atau & \\
peace bulding education. Pendidikan tersebut & \\
tetap memperhatikan kemampuan orientasi, \\
kemampuan persepsi atau menghargai perbedaan, \\
komampuan saling percaya, dan kemampuan \\
emosi atau kecerdasan emosi, kemampuan \\
berkomunikasi, kemampuan berfikir kreatif, dan \\
kemampuan berfikir kritis. \\
Kata Kunci : Pendidikan, Resolusi Konflik, dan \\
Anak Usia Dini.
\end{tabular}

\section{Pendahuluan}

Konflik merupakan keniscayaan dalam kehidupan manusia, termasuk kehidupan anak usia dini. Resolusi konflik termasuk pada suatu pendekatan yang berorientasi pada proses yang mengarahkan pada bentuk komunikasi, dari pelaku maupun pihak luar terhadap kepentingan (interests) dan interpretasi, pihak di luar yang berkonflik sebagai pihak ketiga, yang diperlukannya adalah informasi yang akurat tentang situasi konflik. Hal ini karena komunikasi efektif di antara pelaku dapat terjadi jika ada kepercayaan terhadap pihak ketiga.

Bahwa dalam resolusi konflik terdapat langkah-langkah yang diambil para pelaku atau pihak ketiga dalam rangka mengarahkan perselisihan ke arah hasil tertentu yang mungkin atau tidak mungkin menghasilkan suatu akhir berupa penyelesaian konflik dan mungkin 


\begin{tabular}{|l|l|r|}
\hline A1 Fitrah & Pendidikan Resolusi Konflik Bagi Anak \\
Usia Dini \\
\hline Journal Of Early Childhood Islamic Education & Wira Hadi Kusuma \\
\hline ISSN : 2599-2287 E-ISSN : 2622-335X & \\
Vol.2 No.1 Juli 2018 & \\
\hline
\end{tabular}

atau tidak mungkin menghasilkan

hal ini sangat dipengaruhi oleh stimulus ketenangan, hal positif, kreatif, bermufakat, yang mempengaruhinya, sehingga atau agresif. Resolusi konflik dapat pendidikan resolusi konflik menjadi penting melakukan dengan bantuan diri sendiri, untuk diperhatikan dan harus mendapat kerjasama dalam memecahkan masalah perhatian khusus. Selain ini usia dini dalam pengambilan keputusan oleh pihak memiliki potensi besar dalam membangun ketiga, pendekatan yang berorientasi pada suasana bangsa dan negara Indonesia masa proses resolusi konflik menunjuk pada pola yang akan datang yang harmoni dan dapat komunikasi para pelaku dan cara mereka menyelesaikan masalah dengan pendekatan mempengaruhi kepentingan dan penafsiran konstruktif. Usia 0-6 tahun adalah usia terhadap konflik. Pencegahan konflik, emas yang sangat efektif dalam bertujuan untuk mencegah timbulnya menanamkan dan melatih serta konflik yang keras. ${ }^{1}$ Istilah transformasi membiasakan semua aspek pendidikan konflik secara lebih umum dalam nilai, baik positif maupun negatif.

menggambarkan situasi secara keseluruhan.

Kajian ini akan mendeskripsikan

Pendidikan resolusi konflik sejak anak usia dini merupakan sesuatu yang sangat penting dan harus mendapat perhatian semua pihak. Anak usia dini secara psikologis dan sosiologis sedang mengalami perkembangan yang sudah sudah maju dan berkembang dengan cepat

1 Rubaidi, "Diseminasi Pendidikan Perdamaian Berbasis Agama: Gagasan Intensifikasi Konsep Peace building Berbasis Agama", dalam Thohah Hamim, Resolusi Konflik Islam Indonesia (Yogyakarta: LKiS, 2007), hlm. 72-75.

tentang implimentasi pendidikan resolusi konflik bagi anak usia dini, hal ini berangkat dari kegelisahan akademik penulis tentang realitas perilaku anak-anak bangsa yang cenderung menggunakan nilainilai kekerasan bersifat destruktif dalam menyelesaikan berbagai masalah-masalah yang terjadi. Perbedaan-perbedaan bersifat 


\begin{tabular}{|c|c|c|}
\hline 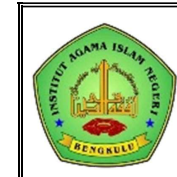 & $\begin{array}{l}\text { A1 Fitrah } \\
\text { Journal Of Early Childhood Islamic Education } \\
\text { ISSN : 2599-2287 E-ISSN : 2622-335X } \\
\text { Vol.2 No.1 Juli } 2018\end{array}$ & $\begin{array}{r}\text { Pendidikan Resolusi Konflik Bagi Anak } \\
\text { Usia Dini } \\
\text { Wira Hadi Kusuma }\end{array}$ \\
\hline
\end{tabular}

furu iyah dapat menghancurkan tatanan

kekeluargaan, kebangsaan dan keagamaan.

\section{Pendidikan Resolusi Konflik}

\section{Pengertian Konflik}

Secara bahasa konflik (conflict) berasal dari bahasa latin configere yang berarti saling memukul. Dengan demikian, maka konflik terdapat dua orang atau lebih yang saling "memukul" sehingga menyebabkan pertikaian dalam berbagai aspeknya. Adapun menurut Antonius, dkk konflik adalah suatu tindakan yang berakibat menghalangi, menghambat, atau mengganggu pihak lain yang dapat terjadi antar kelompok masyarakat ataupun dalam hubungan antar pribadi. $^{2}$

Hal ini sejalan dengan pendapat

Morton Deutsch, seorang pionir pendidikan resolusi konflik $^{3}$ yang

2 Antonius Atosokhi Gea, dkk, Relasi dengan Sesama, (Jakarta: Elex Media Komputindo, 2002), hal. 175.

${ }^{3}$ Bunyamin Maftuh. (2005), Implementasi

Model Pembelajaran Resolusi Konflik Melalui Pendidikan Kewarganegaraan Sekolah Menengah menyatakan bahwa dalam konflik, interaksi sosial antar individu atau kelompok lebih dipengaruhi oleh perbedaan daripada oleh persamaan. Sedangkan menurut Scannell konflik adalah suatu hal alami dan normal yang timbul karena perbedaan persepsi, tujuan atau nilai dalam sekelompok individu. ${ }^{4}$ Sedangkan menurut Webster istilah "conflict" dalam bahasa aslinya berarti suatu "perkelahian, peperangan, atau perjuangan"- yaitu berupa konfrontasi fisik antara beberapa pihak. Tetapi arti kata tersebut kemudian berkembang menjadi "ketidaksepakatan yang tajam atau oposisi terhadap beberapa kepentingan, ide, dan lain-lain". 5

Pembagian konflik menurut Hunt dan Metcalf konflik dibagi menjadi dua jenis, yaitu intrapersonal conflict

Atas. Disertasi (tidak diterbitkan) Universitas Pendidikan Indonesia, Bandung), hal. 47.

4 Antonius Atosokhi Gea, dkk, Relasi dengan Sesama, hal. 173.

5 Dikutip Dean G. Pruitt dan Jeffrey Z. Rubin, Social Conflict Escalation, Stalemate, and Settlement, terj. Helly P. Soetjipto dan Sri Mulyantini Soetjipto, Teori Konflik Sosial (Yogyakarta: Pustaka Pelajar, 2004), hal. 9. 


\begin{tabular}{|l|l||r|}
\hline & Al Fitrah & Pendidikan Resolusi Konflik Bagi Anak \\
Usia Dini \\
Journal of Early Childhood Islamic Education \\
ISSN : 2599-2287 E-ISSN : 2622-335X \\
Vol.2 No.1 Juli 2018
\end{tabular}

(konflik intrapersonal) dan interpersonal conflict (konflik interpersonal). ${ }^{6}$ Konflik intrapersonal adalah konflik yang terjadi dalam diri individu sendiri, misalnya ketika keyakinan yang dipegang individu bertentangan dengan nilai budaya masyarakat, atau keinginannya tidak sesuai dengan kemampuannya. Konflik intrapersonal ini bersifat psikologis, yang jika tidak mampu di atasi dengan baik dapat menggangu bagi kesehatan psikologis atau kesehatan mental (mental hygiene) individu yang bersangkutan. Sedangkan konflik interpersonal ialah konflik yang terjadi antar individu. Konflik ini terjadi dalam setiap lingkungan sosial, seperti dalam keluarga, kelompok teman sebaya sekolah, masyarakat dan negara. Konflik ini dapat berupa konflik antar individu dan kelompok, baik di dalam sebuah kelompok (intragroup conflict) maupun

${ }^{6}$ Hunt M.P dan Metcalf, Ratio and Inquiry on Societys Closed Areas dalam Educating the Democratic Mind, (New York: State University of New York Press, 1996), hal. 97. antar kelompok (intergroup conflict).

Dalam penelitian ini titik fokusnya adalah pada konflik sosial remaja, dan bukan konflik dalam diri individu (intrapersonal conflict).

Dari beberapa dan banyak definisi konflik yang dikemukakan oleh para pakar, maka dapat dirangkum dan diartikan sebagai berikut: Pertama, konflik adalah bentuk pertentangan alamiah yang dihasilkan oleh individu atau kelompok karena mereka yang terlibat memiliki perbedaan sikap, kepercayaan, nilai-nilai, serta kebutuhan. Kedua, hubungan pertentangan antara dua pihak atau lebih (individu maupun kelompok) yang memiliki atau merasa memiliki sasaran-sasaran tertentu, namun diliputi pemikiran, perasaan, atau perbuatan yang tidak sejalan. ${ }^{7}$ Ketiga, pertentangan atau pertikaian karena ada perbedaan dalam kebutuhan, nilai, dan motifasi pelaku atau yang terlibat di

${ }^{7}$ Depag RI, Manajemen Konflik Umat Beragama (Jakarta: Depag RI FKUB, 2003), hlm. 28. 


\begin{tabular}{|l|l|r|}
\hline & Al Fitrah & \\
Journal Of Early Childhood Islamic Education & Pendidikan Resolusi Konflik Bagi Anak \\
Usia Dini \\
ISSN : 2599-2287 E-ISSN : 2622-335X \\
Vol.2 No.1 Juli 2018
\end{tabular}

dalamnya. Keempat, suatu proses yang

terjadi ketika satu pihak secara negatif mempengaruhi pihak lain, dengan melakukan kekerasan fisik yang membuat orang lain perasaan serta fisiknya terganggu. Kelima, bentuk pertentangan yang bersifat fungsional karena pertentangan semacam itu mendukung tujuan kelompok dan memperbarui tampilan, namun disfungsional karena menghilangkan tampilan kelompok yang sudah ada. Keenam, proses mendapatkan monopoli ganjaran, kekuasaan, pemilikan, dengan menyingkirkan atau melemahkan pesaing. Ketujuh, suatu bentuk perlawanan yang melibatkan dua pihak secara antagonis. Dan Kedelapan, kekacauan rangsangan kontradiktif dalam diri individu. ${ }^{8}$

Sejalan dengan itu menurut Jhon Paul L. "conflict is normal in human relationships, and conflict is a motor of

${ }^{8}$ Alo Liliweri, Prasangka dan Konflik: Komunikasi Lintas Budaya Masyarakat Multikultur (Yogyakarta: LKiS, 2005), hlm. 249-250. change". 9 Beberapa definisi di atas menunjukkan bahwa konflik tidak selalu berarti kekerasan (violence) atau peperangan (war). Hal itu karena banyak konflik yang sebenarnya masih tersimpan dan belum muncul ke permukaan atau yang sering kita sebut sebagai konflik laten (tersembunyi). Dapat menyimpulkan bahwa sekecil apapun perbedaan pendapat dalam masyarakat adalah suatu konflik, walaupun konflik ini belum begitu berdampak negatif kepada masyarakat. Namun demikian, jika hal ini tidak dikelola dengan baik dan benar, tidak menutup kemungkinan perbedaan pendapat bisa berubah menjadi konflik kekerasan.

\section{Faktor - Faktor Penyebab Konflik pada Anak}

Dalam memahami faktor konflik, terdapat beberapa teori yang dapat digunakan untuk memahami

9 Jhon Paul L, The Little Book of Conflict Transformation, (USA: Good Books, 2003), hlm. 4. 


\begin{tabular}{|c|c|c|}
\hline 0.03 & $\begin{array}{l}\text { Al Fitrah } \\
\text { Journal Of Early Childhood Islamic Education } \\
\text { ISSN : 2599-2287 E-ISSN : 2622-335X } \\
\text { Vol.2 No.1 Juli } 2018\end{array}$ & $\begin{array}{r}\text { Pendidikan Resolusi Konflik Bagi Anak } \\
\text { Usia Dini } \\
\text { Wira Hadi Kusuma }\end{array}$ \\
\hline
\end{tabular}

sumber konflik di kalangan pelajar atau anak, di antaranya a) social learning theory, b) social identity theory, dan c) reputation enhancement theory. Menurut Sarlito Wirawan Sarwono dalam kehidupan manusia ada dua jenis belajar yaitu belajar secara fisik dan belajar psikis. ${ }^{10}$ Belajar sosial termasuk dalam belajar psikis dimana seseorang mempelajari perannya dan peran orang lain. Selanjutnya orang tersebut akan menyesuaikan tingkah lakunya sesuai dengan peran sosial yang telah dipelajari itu. Cara yang sangat penting dalam belajar sosial adalah tingkah laku tiruan (imitation).

Sedangkan Bandura dan Walters mengemukakan bahwa tingkah laku tiruan merupakan suatu bentuk asosiasi suatu rangsang dengan rangsang lain. Si peniru akan melakukan tingkah laku yang sama dengan tingkah laku

10 Sarlito Wirawan, Psikologi Remaja, (Jakarta: Raja Grafindo Persada, 2006), hal. 23. model. ${ }^{11}$ Sesuai dengan social learning theory ini, seseorang seringkali terdorong untuk mencontoh perilaku orang lain. Pencontohan perilaku (modelling) ini berlaku untuk perilaku yang baik maupun yang tidak baik. Seorang anak yang melihat suatu tindakan kekerasan yang dilakukan oleh orang dewasa dapat mencontoh tindakan tersebut untuk kemudian mempraktekkannya dalam bentuk tindakan kekerasan baik terhadap teman sebaya maupun lingkungan sekitarnya. Contoh lain dari pandangan social learning theory ini adalah tentang kemungkinan adanya pengaruh dari media massa, seperti televisi. Tayangan kekerasan yang terdapat pada tayangan televisi atau film dapat berpengaruh negatif terhadap remaja.

Sedangkan menurut Hogg dan Abrams yang mengembangkan social identity theory menggambarkan perilaku

11 Sugihartono dkk, Psikologi Pendidikan, (Yogyakarta: UNY Press, 2007), hal. 101. 


\begin{tabular}{|l|l||r|}
\hline & Al Fitrah & \\
Journal Of Early Childhood Islamic Education & Pendidikan Resolusi Konflik Bagi Anak \\
Usia Dini \\
ISSN : 2599-2287 E-ISSN : 2622-335X \\
Vol.2 No.1 Juli 2018
\end{tabular}

individu di dalam dan antar kelompok dapat dijelaskan berdasar keanggotaan mereka dalam kelompok sosial tertentu dan proses identifikasi di dalam kelompoknya. ${ }^{12}$ Selanjutnya Hogg dan Abrams mengklaim bahwa identitas kelompok sosial mempengaruhi identitas diri dan konsep diri individu. Berdasarkan teori ini dapat diketahui bahwa anak yang terlibat konflik antar kelompok seperti berkelahi dikarenakan mereka ingin mengidentifikasi diri mereka dan kelompok mereka, mereka bertujuan untuk melindungi nama baik dirinya dan nama baik kelompoknya.

$$
\text { Teori peningkatan reputasi }
$$
(reputation enhancement theory) yang dikembangkan oleh Emler dan Reicher menjelaskan perilaku individu dalam hubungan dengan individu lain dalam satu kelompok, dimana tiap individu berusaha untuk mempunyai reputasi

12 Bunyamin Maftuh. (2005), Implementasi Model Pembelajaran Resolusi Konflik Melalui Pendidikan Kewarganegaraan Sekolah Menengah Atas. Disertasi, hal . 83. yang baik di hadapan teman-teman kelompoknya. $^{13}$ Jadi menurut teori ini, keterlibatan pelajar dalam setiap aksi konflik merupakan salah satu upaya mereka untuk berusaha mendapatkan reputasi baik di mata teman-teman satu kelompoknya. Dari berbagai macam teori tersebut di atas, dapat diketahui bahwa sumber atau penyebab konflik pada pelajar sangat bervariasi. Satu macam konflik mungkin saja berawal dari sumber yang berbeda, sehingga metode penanganan yang diberikan juga berbeda.

\section{Resolusi Konflik}

Resolusi konflik yang dalam bahasa Inggris adalah conflict resolution memiliki makna yang berbeda-beda menurut para ahli yang fokus meneliti tentang konflik. Resolusi dalam Webster Dictionary adalah (1) tindakan mengurai suatu permasalahan, (2) pemecahan, (3)

${ }^{13}$ Bunyamin Maftuh. (2005), Implementasi Model Pembelajaran Resolusi Konflik Melalui Pendidikan Kewarganegaraan Sekolah Menengah Atas. Disertasi, hal . 84. 


\begin{tabular}{|c|c|c|}
\hline & $\begin{array}{l}\text { A1 Fitrah } \\
\text { Journal Of Early Childhood Islamic Education } \\
\text { ISSN : 2599-2287 E-ISSN : 2622-335X } \\
\text { Vol.2 No.1 Juli } 2018\end{array}$ & $\begin{array}{r}\text { Pendidikan Resolusi Konflik Bagi Anak } \\
\text { Usia Dini } \\
\text { Wira Hadi Kusuma }\end{array}$ \\
\hline
\end{tabular}

penghapusan atau penghilangan permasalahan. Hal ini juga sejalan dengan ini, Weitzman dan Weitzman mendefinisikan resolusi konflik sebagai sebuah tindakan pemecahan masalah bersama (solve a problem together). ${ }^{14}$ Lain halnya dengan Fisher yang menjelaskan bahwa resolusi konflik adalah usaha menangani sebab-sebab konflik dan berusaha membangun hubungan baru yang bisa tahan lama di antara kelompok-kelompok yang berseteru. $^{15}$

Dari pemaparan teori menurut para ahli tersebut, maka dapat ditarik kesimpulan bahwa yang dimaksud dengan resolusi konflik adalah suatu cara individu untuk menyelesaikan masalah yang sedang dihadapi dengan individu lain secara sukarela. Resolusi konflik juga menyarankan penggunaan cara-cara

14 Morton Deutsch dan Colemen, The Handbook of Conflict Resolution, Theory and Practice, (San Fransisco: Jossey Bass Publisher, 2006), hal. 197.

15 Simon Fisher, Mengelola Konflik, Keterampailan dan Strategi untuk Bertindak, (Jakarta: The British Council, 2001), hal. 7. yang lebih demokratis dan konstruktif untuk menyelesaikan konflik dengan memberikan kesempatan pada pihakpihak yang berkonflik untuk memecahkan masalah mereka oleh mereka sendiri atau dengan melibatkan pihak ketiga yang bijak, netral dan adil untuk membantu pihak-pihak yang berkonflik memecahkan masalahnya.

\section{Pendidikan Anak Usia Dini}

Pendidikan anak usia dini menurut Maimunah Hasan dalam bukunya berjudul "PAUD", adalah:

Pendidikan anak usia dini adalah jenjang pendidikan sebelum jenjang pendidikan dasar, yang merupakan suatu upaya pembinaan yang ditujukan bagi anak-anak usia lahir sampai usia enam tahun, yang diberikan rangsangan untuk membantu pertumbuhan dan perkembangan jasmani dan rohani, agar anak memiliki kesiapan dalam memasuki pendidikan lanjut, baik diselenggarakan melalui jalur 


\begin{tabular}{|l|l||r|}
\hline & Al Fitrah & \\
Journal Of Early Childhood Islamic Education & Pendidikan Resolusi Konflik Bagi Anak \\
ISSN $: 2599-2287$ E-ISSN $: 2622-335 X$ & Usia Dini \\
& Wol.2 No.1 Juli 2018 & Wira Hadi Kusuma \\
\hline
\end{tabular}

formal, nonformal mapun nonformal. $^{16}$

Dengan demikian, pendidikan anak usia dini merupakan suatu aktivitas pendidikan dilakukan secara sadar dan bertanggung jawab untuk melakukan pembinaan yang berkaitan dengan hal-hal positif terhadap perilaku anak usia dini. Pengaruh yang positif ini harus diberikan pada anak usia dini dengan menggunakan program yang terencana, sistematis dan berkelanjutan dalam bentuk interaksi edukatif antara pendidik dan anak. Terencana mengandung pengertian bahwa program pendidikan yang akan diberikan telah dirumuskan, disusun dan ditentukan secara logis dan sesuai dengan kebutuhan perkembangan potensi anak.

Dari penjelasan di atas dapat jelaskan bahwa pendidikan anak usia dini memiliki tujuan yaitu: Pertama, memberikan pengaruh positif yang

16 Maimunah Hasan, PAUD: Pendidikan Anak Usia Dini Panduan Lengkap Manajemen Pendidikan Mutu Anak Untuk Para Guru dan Orang Tua (Yogyakarta: Diva Press, 2009), hal. 15.

diharapkan akan menjadi kerangka dasar (fondasi) bagi anak usia dini dalam menyesuaikan diri dengan lingkungannya, serta bagi pertumbuhan dan perkembangan selanjutnya. Anak yang memiliki kerangka dasar (fondasi) yang kuat ketika usia dini maka akan menjadi dasar dan penopang bagi perkembangan anak memasuki pendidikan lanjutan, berkarir maupun hidup di tengah kehidupan masyarakat, lain halnya dengan sebaliknya. ${ }^{17}$ Kedua, Intervensi dini dengan diberikan rangsangan pendidikan, sehingga menumbuhkan potensi-potensi yang tersembunyi (hidden potency) serta mengembangkan potensi tampak (actual potency) yang terdapat pada diri anak. ${ }^{18}$ Ketiga, melakukan diteksi dini terhadap kemungkinan terjadinya gangguan dalam pertumbuhan dan perkembangan potensipotensi anak, dan diharapkan gangguan-

\footnotetext{
17 Maimunah Hasan, PAUD: Pendidikan Anak, hlm. 17.

18 Depdiknas, Pendidikan dan Latihan, hlm. 45.
} 


\begin{tabular}{|l|l||r|}
\hline A1 Fitrah & Pendidikan Resolusi Konflik Bagi Anak \\
Usia Dini \\
\hline Journal Of Early Childhood Islamic Education & Wira Hadi Kusuma \\
\hline ISSN : 2599-2287 E-ISSN : 2622-335X & \\
Vol.2 No.1 Juli 2018 & \\
\hline
\end{tabular}

gangguan tersebut dapat diminimalisasikan

atau diobati secara dini.

Pendidikan anak usia dini sangat penting jika diaplikasikan dalam hal resolusi konflik, karena usia 0-6 tahun merupakan usia emas yang sangat efektif dalam menanamkan, membiasakan dan mempraktekkan nilai-nilai damai, misalnya saling memaafkan, saling menyayangi, saling berbagi dan saling toleransi.

\section{Pendidikan Resolusi Konflik bagi Anak}

Usia Dini

Institusi pendidikan formal

mempunyai tugas dan kewajiban dalam membentuk pola peserta didik yang meliputi pola cipta, rasa, dan karsa. Dalam hal ini pendidikan tidak semata-mata memberi informasi dan pengetahuan saja akan tetapi juga bertugas membentuk kesadaran bertanggung jawab dan pengambilan keputusan yang baik pada peserta didik. Tanggung jawab dan pengambilan keputusan yang baik ini diharapkan dapat membawa individu menjadi manusia seutuhnya dan mampu mengendalikan diri dalam lingkungan sosialnya.

Pentingnya pendidikan untuk menyelesaikan atau resolusi konflik dan menciptakan kehidupan yang damai adalah sejalan dengan salah satu pilar pendidikan yang dinyatakan oleh UNESCO yaitu learning how to live together in harmony. ${ }^{19}$ Pendidikan menuju perdamaian ini juga telah dikemukakan oleh $\mathrm{Ki}$ Hadjar Dewantara sejak tahun 1920. Beliau menekankan tentang pentingnya pendidikan yang didasarkan pada asas tertib dan damai. Pengimplementasian program pengajaran resolusi konflik di sekolah-sekolah di Indonesia adalah sejalan dengan kebijakan dan strategi pendidikan nasional jangka panjang, yaitu mendorong pendidikan perdamaian dan pendidikan global.

Pendidikan damai merupakan suatu keharusan yang harus dikembangkan dalam

${ }^{19}$ Bunyamin Maftuh. (2005), Implementasi Model Pembelajaran Resolusi Konflik Melalui Pendidikan Kewarganegaraan Sekolah Menengah Atas. Disertasi, hal . 20. 


\begin{tabular}{|l|l||r|}
\hline & Al Fitrah & \\
Journal Of Early Childhood Islamic Education & Pendidikan Resolusi Konflik Bagi Anak \\
Usia Dini \\
ISSN : 2599-2287 E-ISSN : 2622-335X \\
Vol.2 No.1 Juli 2018
\end{tabular}

kehidupan anak usia dini. Kebanyakan konflik terjadi karena perbedaan nilai.

Nilai merupakan sesuatu yang menjadi dasar, pedoman, tempat setiap manusia menggantungkan pikiran, perasaan, dan tindakan. Yang termasuk dalam kategori ini adalah konflik yang bersumber pada perbedaan rasa percaya, keyakinan, bahkan ideologi atas apa yang diperebutkan. ${ }^{20}$

Dalam menerapkan pendidikan resolusi konflik bagi anak usia dini sesuai dengan teori resolusi konflik adalah (1) tindakan mengurai suatu permasalahan, (2) pemecahan, (3) penghapusan atau penghilangan permasalahan atau dengan kata lain usaha menangani sebab-sebab konflik dan berusaha membangun hubungan baru yang bisa tahan lama di antara kelompok-kelompok yang berseteru. ${ }^{21}$ Sebagai seorang pendidik atau pemerhati atau peduli terhadap pendidikan

${ }^{20}$ Agus Sriyanto, "Penyelesaian Konflik Berbasis Budaya Lokal “, IBDA 'Jurnal Studi Islam dan Budaya, Vol. 5, No. 2, Jul-Des 2007, hlm. 4.

21 Simon Fisher, Mengelola Konflik, Keterampailan dan Strategi untuk Bertindak, (Jakarta: The British Council, 2001), hal. 7. anak usia dini seyogyanya memperhatikan tiga aspek tersebut.

Pertama, pendidikan tentang tindakan mengurai sesuatu masalah yang ada pada anak usia dini. Anak usia dini secara psikologis dan sosiologis memiliki karakter jujur dan penyelesaian yang unik, sehingga diperlukan guru atau orang tua yang harus mengurai akar masalahnya atau akar penyebab pertikaian terjadi antara anak satu dengan lainnya. Tahap ini adalah upaya penting dilakukan untuk merumuskan dimana letak kesahpahaman satu sama lain, sehingga guru dan orangtua dapat mencari solusi kemngkinan penyelesaiannya.

Kedua, pendidikan tentang pemecahan masalah, pada tahap ini setiap guru atau orang tua mencari solusi terhadap masalah yang dihadapi anak, anak yang tingkat kesalahannya besar atau mengetahui dan mengakui bahwa dirinya salah, dan tingkat kesalahan yang kecil juga diharapkan mampu mengetahui dan 


\begin{tabular}{|l|l||r|}
\hline A1 Fitrah & Pendidikan Resolusi Konflik Bagi Anak \\
Usia Dini \\
\hline Journal Of Early Childhood Islamic Education & Wira Hadi Kusuma \\
\hline ISSN : 2599-2287 E-ISSN : 2622-335X & \\
Vol.2 No.1 Juli 2018 & \\
\hline
\end{tabular}

mengakui bahwa dia juga telah melakukan

perilaku salah. Setelah keduanya

mengetahui tingkat kesalahan masing-

masing, selanjutnya tawaran solusi untuk

saling memaafkankan, yang tingkat

kesalahannya besar untuk terlebih dahulu meminta maaf, dan begitu sebaliknya.

Ketiga, pendidikan tentang

menghilangkan permasalahan. Setelah dua

tahapan sebelumnya, tahap ini berupaya

untuk menangani sebab-sebab konflik

secara mendalam dan berusaha membangun

hubungan baru yang bisa tahan lama di

antara anak satu dengan yang lainnya. Atau

dengan kata lain saling memaafkan, saling

berjabat tangan dan saling berpelukan.

Bahwa jika merujuk pola penyelesaian

konflik berbasis budaya lokal dengan cara

"angkat saudara" atau "menjadi saudara

angkat". Dengan demikian Peace Building

Education bagi anak usia dini menjadi

sesuatu yang harus dibudayakan dalam

berbagai level dan lingkungan. Sebagai

seorang guru atau orang tua yang memiliki pengetahuan tentang Peace Building

Education harus mengacu pada kemampuan

keseluruhan aktivitas yang ditujukan pada

pencegahan perpecahan, semakin meluas atau berkelanjutan kepada konflik destruktif, yang melibatkan orang tua atau wali anak usia dini, padahal diharapkan dapat membangun sikap kooperatif lintas sektoral. $^{22}$

Dalam konteks pendidikan resolusi konflik pada anak usia dini dapat beberapa istilah, yakni (1) pencegahan konflik; pola ini bertujuan untuk mencegah timbulnya kekerasan dalam konflik pada anak usia dini, (2) penyelesaian konflik; bertujuan untuk mengakhiri kekerasan melalui persetujuan perdamaian dan saling memaafkan, (3) pengelolaan konflik; bertujuan membatasi atau menghindari kekerasan melalui atau mendorong perubahan anak usia dini yang terlibat konflik agar berperilaku positif; (4) resolusi

22 Rubaidi, "Diseminasi Pendidikan Perdamaian Berbasis Agama: Gagasan Intensifikasi Konsep Peace building Berbasis Agama", dalam Thohah Hamim, Resolusi Konflik Islam Indonesia (Yogyakarta: LKiS, 2007), hlm. 72-75. 


\begin{tabular}{|c|c|c|}
\hline$\Leftrightarrow$ & $\begin{array}{l}\text { Al Fitrah } \\
\text { Journal Of Early Childhood Islamic Education } \\
\text { ISSN : 2599-2287 E-ISSN : 2622-335X } \\
\text { Vol.2 No.1 Juli } 2018\end{array}$ & $\begin{array}{r}\text { Pendidikan Resolusi Konflik Bagi Anak } \\
\text { Usia Dini } \\
\text { Wira Hadi Kusuma }\end{array}$ \\
\hline
\end{tabular}

konflik; bertujuan menangani sebab-sebab

konflik, dan berusaha membangun

hubungan baru yang relatif dapat bertahan

lama di antara anak-anak yang bermusuhan,

(5) transformasi konflik; yakni mengatasi sumber-sumber konflik yang akan berakibat yang lebih luas, dengan mengalihkan kekuatan negatif dari sumber perbedaan kepada kekuatan positif. $^{23}$ Dalam konteks ini, maka guru anak usia dini dan orang tua, diharapkan mengetahui pola dan tingkatan

\footnotetext{
${ }^{23}$ Simon Fisher, Mengelola Konflik: Ketrampilan dan Strategi Untuk Bertindak (Jakarta: The British Council, 2001), hlm. 14. Lihat juga Jhon Paul L, dalam bukunya The Little Book of Conflict Transformation, USA: Good Books, 2003. Paul menjelaskan bahwa Teori Transformasi konflik bertujuan mengubah cara pandang (mindset) seseorang dari anggapan konflik sesuatu yang negatif menjadi yang positif. Pada dasarnya konflik adalah sesuatu yang normal dalam kehidupan manusia yang berhubungan satu sama lain, yang berbeda suku, bangsa, agama, ras, adat istiadat dan lain-lain. Kenaturalan konflik itu harus dipahami sebagai langkah menuju perubahan yang lebih baik. Hal ini sanada dengan ungkapan Jhon Paul L. "conflict is normal in human relationships, and conflict is a motor of change", hal. 4. Ungkapan itu memang sesuatu yang menginspirasikan, selanjutnya bagaimana konflik yang ada dikelolah menjadi sesuatu yang dapat mengubah atau membangun dan memberikan perubahan kepada personal, relationships, structure and culture, hal. 23. Untuk mewujudkan hal itu tentu saja memerlukan waktu yang relatif lama atau program jangka panjang. Adapun konsep transfomasi konflik didefinisikan, "conflict transformation is to envision and respond to the ebb and flow of social conflict as life-giving opportunities for creating constructive change process that reduce violence, increace justice in direct interaction and social structure and respond to real-life problems in human relationships, hal. 14 .
}

konflik yang dimiliki anak, selanjutnya dapat di terapkan pola pendidikan resolusi konflik yang bersifat jangka panjang, agar pertikaian antar anak usia dini menjadi lebih positif bahkan lebih dari itu dapat mengembangkan pendidikan damai di masa yang akan datang.

Sejalan dengan pendapat Scannell juga menyebutkan aspek -aspek yang mempengaruhi individu untuk dapat memahami dan meresolusi sebuah konflik meliputi a) keterampilan berkomunikasi, b) kemampuan menghargai perbedaan, c) kepercayaan terhadap sesama, dan d) kecerdasan emosi. Aspek tersebut jika dikontektualisasikan dalam pendidikan resolusi konflik bagi anak usia dini dengan penjelasan sebagai berikut:

Pertama, pendidikan keterampilan berkomunikasi. Masing-masing anak usia dini sebaiknya dikembangkan pola pendidikan yang melatih keterampilan berkomunikasi agar dalam menyelesaikan masalah anak dapat dengan mudah 


\begin{tabular}{|l|l|r|}
\hline A1 Fitrah & Pendidikan Resolusi Konflik Bagi Anak \\
Usia Dini \\
\hline Journal Of Early Childhood Islamic Education & Wira Hadi Kusuma \\
\hline ISSN : 2599-2287 E-ISSN : 2622-335X & \\
Vol.2 No.1 Juli 2018 & \\
\hline
\end{tabular}

dideteksi. Keterampilan terbuka saling menghargai merupakan hal penting dalam proses resolusi konflik, terutama bagi anak usia dini. Keterampilan menyampaikan gagasan, ide, pendapat dan perasaan pada masing-masing anak dapat juga membantu dalam penyelesaian konflik anak usia dini.

Kedua, pendidikan dan kemampuan untuk saling menghargai perbedaan. Anak usia dini yang sudah mampu berkomunikasi dengan baik, selanjutnya diarahkan untuk menghargai perbedaan dengan bahasa dan contoh-contoh yang sejalan usia anak. Kemampuan saling menghargai perbedaan juga merupakan salah satu akar konflik yang akan berlangsung lama, karena perbedaan adalah sunnatullah, sehingga perbedaan menjadi rahmat. Sebagai guru dan orang tua harus mengembangkan pola pendidikan melihat perbedaan sebagai keniscayaan dan harus dihargai sebagai keunikan ciptaan Allah swt.

Ketiga, pendidikan kepercayaan kepada sesama. Anak usia dini adalah usia peniruan kepada orang yang ia idolakan, termasuk guru dan oarng tuanya. Membangun kepercayaan kepada diri sendiri dan kepercayaan kepada orang lain, merupakan salah satu keterampilan penting dalam meresolusi konflik. Anak-anak usia dini harus dibangun rasa percaya diri dan juga percaya kepada orang lain, bahwa orang lain juga adalah orang yang baik dan saling sayang satu sama lainnya.

Keempat, pendidikan yang meningkatkan kecerdasan emosi. Pendidikan emosi bagi guru dan orang tua tentang anak juga menjadi penentu dalam menyelesaikan konflik. Misalnya anak di didik untuk saling memaafkan, sikap dan perilaku memaafkan tidak semua anak mudah mepraktekkannya. Hal ini sangat tergantung pada pola pendidikan dan kbiasaan disekolah, di rumah dan dilingkungan masyarakat berada, anak yang telah dilatih dengan membiasakan diri memaafkan akan meningkatkan kecerdasan emosi anak usia dini secara baik pula. 


\begin{tabular}{|l|l||r|}
\hline & Al Fitrah & \\
Journal Of Early Childhood Islamic Education & Pendidikan Resolusi Konflik Bagi Anak \\
ISSN $: 2599-2287$ E-ISSN $: 2622-335 X$ & Usia Dini \\
& Wol.2 No.1 Juli 2018 & Wira Hadi Kusuma \\
\hline
\end{tabular}

Dari pemaparan tersebut di atas dapat diketahui bahwa dalam proses resolusi konflik diperlukan kemampuankemampuan tertentu untuk mencari solusi konflik secara konstruktif. Kemampuan tersebut di antaranya adalah kemampuan orientasi, kemampuan persepsi atau menghargai perbedaan, komampuan saling percaya, dan kemampuan emosi atau kecerdasan emosi, kemampuan berkomunikasi, kemampuan berfikir kreatif, dan kemampuan berfikir kritis.

\section{Kesimpulan}

Pendidikan resolusi konflik pada anak usia dini merupakan hal yang sangat urgen. Hal ini disebabkan anak usia dini adalah pondasi awal dalam penanaman dan penegnalan serta pembiasaan karakter tentang pembentukan nilai-nilai dasar. Bagi para guru atau orangtua dalam mengembangkan pendidikan resolusi konflik bagi anak usia dini, hendaknya mengetahui tentang pendidikan menguraikan masalah, pemecahan masalah dan menghilangkan permasalahan atau peace bulding education. Dengan memperhatikan kemampuan orientasi, kemampuan persepsi atau menghargai perbedaan, komampuan saling percaya, dan kemampuan emosi atau kecerdasan emosi, kemampuan berkomunikasi, kemampuan berfikir kreatif, dan kemampuan berfikir kritis.

\section{Daftar Pustaka}

Atosokhi, Antonius Gea, dkk, 2002. Relasi dengan Sesama, Jakarta: Elex Media Komputindo.

Depag RI, Manajemen Konflik Umat Beragama (Jakarta: Depag RI FKUB, 2003), hlm. 28.

Depdiknas. 2008. Pendidikan dan Latihan Profesi Guru (PLPG) Sertifikasi Guru dalam Jabatan Tahun 2008; Taman Kanak-kanak, Jakarta: Depdiknas.

Deutsch, Morton dan Colemen, 2006. The Handbook of Conflict Resolution, Theory and Practice, San Fransisco: Jossey Bass Publisher.

Fisher, Simon, 2001Mengelola Konflik, Keterampailan dan Strategi untuk Bertindak, (Jakarta: The British Council.

Hasan, Maimunah. 2009. PAUD: Pendidikan Anak Usia Dini Panduan Lengkap Manajemen Pendidikan Mutu Anak 


\begin{tabular}{|l|l|r|}
\hline A1 Fitrah & Pendidikan Resolusi Konflik Bagi Anak \\
Usia Dini \\
\hline Journal Of Early Childhood Islamic Education & Wira Hadi Kusuma \\
\hline ISSN : 2599-2287 E-ISSN : 2622-335X & \\
Vol.2 No.1 Juli 2018 & \\
\hline
\end{tabular}

Untuk Para Guru dan Orang Tua, Yogyakarta: Diva Press.

Hunt M.P dan Metcalf, 1996. Ratio and Wirawan, Sarlito, 2006. Psikologi Remaja, Jakarta: Raja Grafindo Persada. Inquiry on Societys Closed Areas dalam Educating the Democratic Mind, New York: State University of New York Press.

Liliweri, Alo, 2005. Prasangka dan Konflik: Komunikasi Lintas Budaya Masyarakat Multikultur (Yogyakarta: LkiS.

Maftuh, Bunyamin. (2005), Implementasi Model Pembelajaran Resolusi Konflik Melalui Pendidikan Kewarganegaraan Sekolah Menengah Atas. Disertasi (tidak diterbitkan) Universitas Pendidikan Indonesia, Bandung.

Paul L, Jhon, 2003. The Little Book of Conflict Transformation, USA: Good Books

Pruitt, Dean G. dan Jeffrey Z. Rubin, 2004. Social Conflict Escalation, Stalemate, and Settlement, terj. Helly P. Soetjipto dan Sri Mulyantini Soetjipto, Teori Konflik Sosial, Yogyakarta: Pustaka Pelajar.

Rubaidi, 2007. "Diseminasi Pendidikan Perdamaian Berbasis Agama: Gagasan Intensifikasi Konsep Peace building Berbasis Agama", dalam Thohah Hamim, Resolusi Konflik Islam Indonesia. Yogyakarta: LkiS.

Sugihartono dkk, 2007. Psikologi Pendidikan, Yogyakarta: UNY Press.

Sriyanto, Agus, "Penyelesaian Konflik Berbasis Budaya Lokal ", IBDA Jurnal Studi Islam dan Budaya, Vol. 5, No. 2, Jul-Des 2007. 